\title{
EDITORIAL
}

\section{Corrosion Today 2008}

\section{Kazimierz Darowicki}

Published online: 10 March 2009

(C) Springer-Verlag 2009

The international conference "Corrosion Today" organised by the Department of Electrochemistry, Corrosion and Materials Engineering of Gdansk University of Technology was held between 23 and 26 April 2008 in GdańskSobieszewo, Poland. It was held under the auspices of the European Federation of Corrosion.

The aim of the conference was to allow exchange of knowledge and experience as well as promote cooperation between scientists acting in the field of corrosion and anticorrosion protection. The conference was dedicated to Prof. Stanisław Mrowec to honour the 80th birthday of this remarkable scientist and teacher, whose contribution to understanding corrosion is difficult to overestimate.

The conference was attended by 131 participants from Finland, Sweden, Germany, France, Romania, Russia, Turkey, Libya and Poland. The plenary lectures were given by Prof. Michael Schutze, President of the European
Federation of Corrosion, on "Current technological needs for high temperature corrosion research", Prof. Stanisław Mrowec from AGH University of Science and Technology on "Dissociative mechanism of scales growth on metals and alloys", Prof. Krzysztof Jan Kurzydłowski, Under-Secretary of State in Ministry of Science and Higher Education, on "Microstructural aspects of the corrosion of modern metallic materials" and Prof. Janusz Flis from Institute of Physical Chemistry of Polish Academy of Sciences. Eightytwo section lectures were delivered in the following sections: Physico-chemical Methods of Corrosion Testing, Surface Science, Local Corrosion and Passivation, Corrosion Technologies and Fundamentals of Corrosion.

During the plenary discussion, it was decided that the next conference from this series will be organised in 2011 in Krakow, Poland by the AGH University of Science and Technology.

K. Darowicki $(\bowtie)$

Faculty of Chemistry, Department of Electrochemistry,

Corrosion and Materials Engineering,

Gdansk University of Technology,

ul. Narutowicza 11/12,

80-952 Gdansk, Poland

e-mail: zak@chem.pg.gda.pl 